Article

\title{
Soil Microbial Community Changes in a Field Treatment with Chlorotoluron, Flufenacet and Diflufenican and Two Organic Amendments
}

\author{
María José Carpio ${ }^{1}$, Carlos García-Delgado ${ }^{1,2}{ }^{\mathbb{D}}$, Jesús María Marín-Benito ${ }^{1}$, \\ María Jesús Sánchez-Martín ${ }^{1}$ and María Sonia Rodríguez-Cruz ${ }^{1, * \mathbb{D}}$ \\ 1 Institute of Natural Resources and Agrobiology of Salamanca (IRNASA-CSIC), Cordel de Merinas 40-52, \\ 37008 Salamanca, Spain; mjose.carpio@irnasa.csic.es (M.J.C.); carlos.garciadelgado@uam.es (C.G.-D.); \\ jesusm.marin@irnasa.csic.es (J.M.M.-B.); mjesus.sanchez@irnasa.csic.es (M.J.S.-M.) \\ 2 Department of Geology and Geochemistry, Autonomous University of Madrid, 28049 Madrid, Spain \\ * Correspondence: msonia.rodriguez@irnasa.csic.es; Tel.: +34-923-219-606
}

Received: 3 July 2020; Accepted: 6 August 2020; Published: 8 August 2020

\begin{abstract}
The soil microbial activity, biomass and structure were evaluated in an unamended (S) and organically amended soil treated with two commercial formulations of the herbicides chlorotoluron (Erturon ${ }^{\circledR}$ ) and flufenacet plus diflufenican (Herold ${ }^{\circledR}$ ) under field conditions. Soils were amended with spent mushroom substrate (SMS) or green compost (GC). Soil microbial dehydrogenase activity (DHA), biomass and structure determined by the phospholipid fatty acid (PLFA) profiles were recorded at $0,45,145,229$ and 339 days after herbicide treatment. The soil DHA values steadily decreased over time in the unamended soil treated with the herbicides, while microbial activity was constant in the amended soils. The amended soils recorded higher values of concentrations of PLFAs. Total soil microbial biomass decreased over time regardless of the organic amendment or the herbicide. Herbicide application sharply decreased the microbial population, with a significant modification of the microbial structure in the unamended soil. In contrast, no significant differences in microbial biomass and structure were detected in S + SMS and S + GC, untreated or treated with herbicides. The application of SMS and GC led to a significant shift in the soil microbial community regardless of the herbicides. The use of SMS and GC as organic amendments had a certain buffer effect on soil DHA and microbial biomass and structure after herbicide application due to the higher adsorption capacity of herbicides by the amended soils.
\end{abstract}

Keywords: herbicides; field experiment; soil; green compost; spent mushroom substrate; bioindicators

\section{Introduction}

Pesticides are used intensively in modern agriculture to increase and protect crop yields [1,2]. However, their increasing use poses a potential hazard for the environment due to their persistence in soil, their toxicity to non-target organisms, and the increase in resistant species [3,4]. The presence of certain pesticides and their degradation products may alter the functional balance of the soil ecosystem, as they may promote, inhibit or even have no effect on the growth of most soil-dwelling microorganisms when applied at agronomical rates [2,5]. In turn, they may have a positive, negative or no effect on the structure and diversity of microbial communities and soil enzymatic activities [1,6,7].

The use of organic amendments rich in nutrients and organic matter $(\mathrm{OM})$ is a common practice in agriculture and soil remediation processes $[4,8-10]$. This practice is often used to increase crop yields, improve soil quality and fertility, preserve the soil from degradation, mitigate pesticide leaching, and enhance soil microbial activity [6,11]. Organic residues with a potential value are those from 
agricultural, industrial, and urban activities, such as the composted spent mushroom substrate (SMS) and green compost (GC) $[12,13]$. The OM of these residues may modify the persistence, dynamics, and environmental fate of herbicides applied to amended soils [14,15].

Generally, organic amendments alter the biodegradation of pesticides, increasing sorption and reducing bioavailability to microorganisms by introducing exogenous microorganisms with biodegradation abilities, or by modifying soil properties, and consequently changing the structure and activity of native microbiota $[13,16]$. Some soil properties such as microbial biomass and enzymatic activities and in particular dehydrogenase activity (DHA) are used as bioindicators of changes in the soil after agricultural management practices involving the application of herbicides and organic amendments [6,17-19].

Chlorotoluron, flufenacet, and diflufenican are herbicides extensively applied in agriculture in preand post-emergence for the selective control of grasses and certain broad-leaved weeds in winter cereals and other crops. These compounds belong to different substance groups (phenylurea, oxyacetamide, and carboxamide, respectively) and have different hydrophobicity [20].

A previous laboratory study assessed the degradation kinetics of chlorotoluron and flufenacet at temperatures of 6 and $16^{\circ} \mathrm{C}$ in an unamended soil and one amended with SMS and GC. The application of the organic amendments to soil decreased the degradation rates of both herbicides due to their higher sorption and lower bioavailability for degradation in amended soil. An expected faster degradation was observed at a higher temperature due to increased microbiological activity [21].

Little is known about the effects these herbicides and organic residues have on the various groups of soil microorganisms when they are applied jointly. Most of the studies on soil microbial response to pesticides and organic residues have been assessed at laboratory or greenhouse scale [6,14,22-25], but only a few assays have been performed at field scale [13,19]. Moreover, only one study has been found in the literature that refers to the impact on soil microbial activity of the combined application of the herbicide chlorotoluron with organic residues under field conditions [11]. However, several studies have reported the effects of chlorotoluron, flufenacet, and diflufenican on soil microbial communities in unamended soils under laboratory conditions $[7,18,26,27]$. Because of the significance of soil microorganisms in many soil cycles and soil health [28], it is very important to assess the impact that this simultaneous application has on the soil microbial community [19].

The objective here, therefore, was to evaluate the changes in soil microbial communities over time after the application of Erturon ${ }^{\circledR}$ and Herold ${ }^{\circledR}$ commercial formulations of the herbicides chlorotoluron and flufenacet plus diflufenican, respectively, under field conditions. To achieve this objective, a study of bioindicators including overall soil microbial activity and biomass and structure was performed in the unamended and amended soil surface over time. A field experiment was established and the soil dehydrogenase activity (DHA) and the profile of phospholipid fatty acids (PLFAs) extracted from the soil were determined after the application of two organic amendments, SMS and GC. Therefore, we expect that the application of herbicides and organic amendments in an agricultural soil at field scale has an impact on the activity, biomass and structure of soil microbial community over the herbicide dissipation period.

\section{Materials and Methods}

\subsection{Chemicals}

The commercial formulations Erturon ${ }^{\circledR}$ (chlorotoluron 50\% w/v) and Herold ${ }^{\circledR}$ (flufenacet 40\% $w / v$ and diflufenican 20\% w/v) were supplied by Cheminova Agro S.A. (Madrid, Spain), and Bayer Crop Science S.L. (Valencia, Spain), respectively. Analytical standards of chlorotoluron, flufenacet, and diflufenican ( $>97.9 \%$ purity) were supplied by Sigma Aldrich Química S.A. (Madrid, Spain). Their main characteristics are included in Table 1 [20]. 
Table 1. Main characteristics of herbicides.

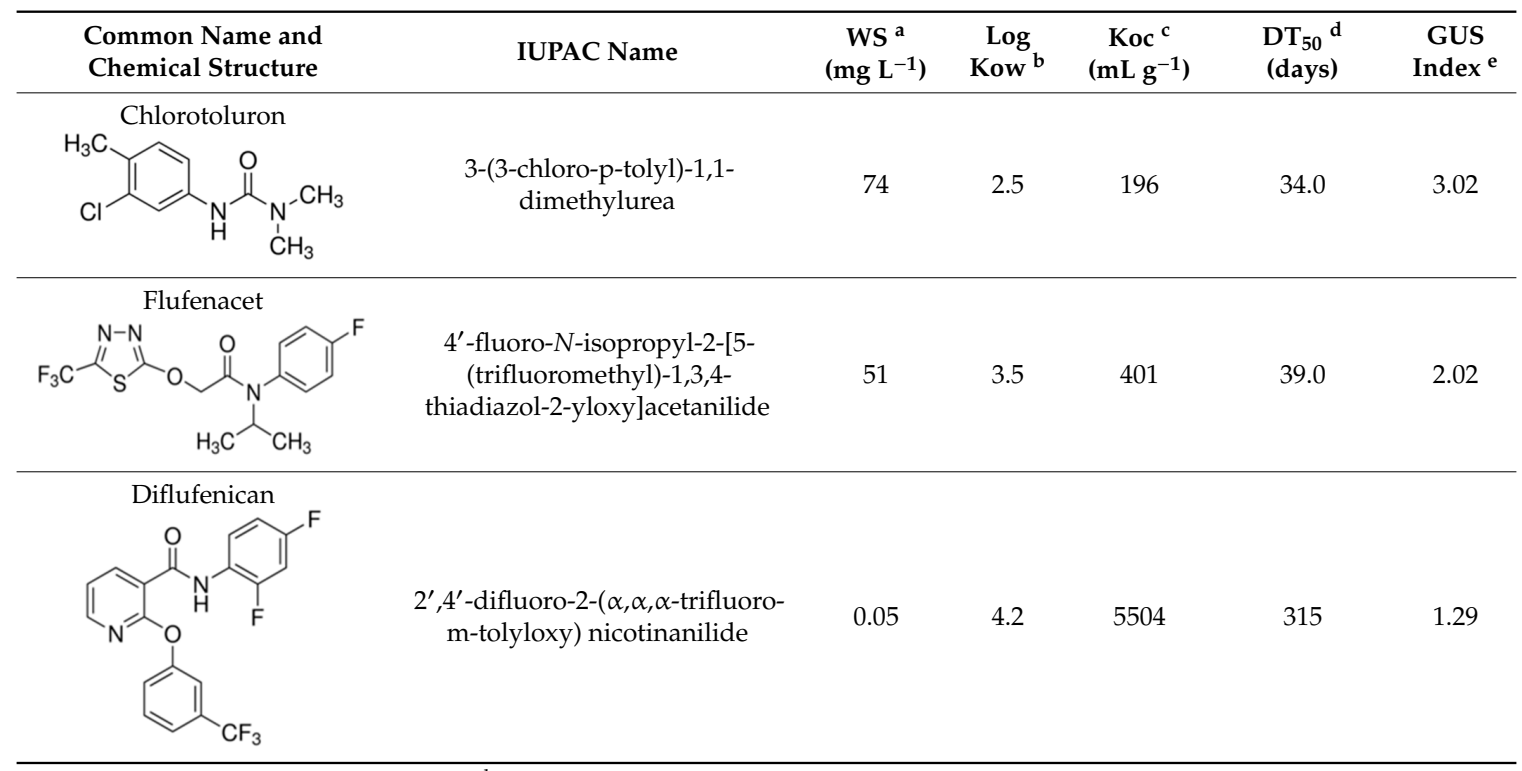

${ }^{\text {a }}$ WS, water solubility at $20{ }^{\circ} \mathrm{C} ;{ }^{b}$ octanol/water partition coefficient at $\mathrm{pH} 7$ and $20{ }^{\circ} \mathrm{C} ;{ }^{\mathrm{c}}$ sorption coefficient normalized to organic carbon content; ${ }^{\mathrm{d}}$ time to degradation of $50 \%$ of compound in field; ${ }^{\mathrm{e}}$ the Gustafson mobility index [20].

\subsection{Soil and Organic Amendments}

The soil was an Eutric-Chromic Cambisol soil with a sandy loam texture (14.9\% clay, $4.7 \%$ silt, and $80.4 \%$ sand). The organic amendments were spent mushroom substrate (SMS) from Agaricus bisporus and Pleurotus ostreatus (2:1) cultivation (Sustratos de la Rioja S.L., Pradejon, Spain) and green compost (GC) from the pruning of plants and trees in parks and gardens (El Arca, S.L., Salamanca, Spain). Both organic residues (size $<2 \mathrm{~mm}$ ) were composted in piles for 2 to 6 months under aerobic conditions. Their main characteristics of soils and organic amendments (Table 2) were determined by the methods reported previously $[29,30]$ for air-dried samples.

Table 2. Characteristics of the organic residues spent mushroom substrate (SMS) and green compost (GC), unamended (S) and amended (S + SMS and S + GC) soils (0-10 cm depth).

\begin{tabular}{cccccc}
\hline Characteristic & SMS & GC & S & S + SMS & S + GC \\
\hline $\mathrm{pH}$ & 7.9 & 7.2 & 6.34 & 7.11 & 6.99 \\
$\mathrm{OM}(\%)^{\mathrm{a}}$ & 59.4 & 46.0 & 1.33 & 4.36 & 2.81 \\
$\mathrm{DOC}(\%)$ b & 0.8 & 0.7 & 0.008 & 0.023 & 0.018 \\
$\mathrm{~N}(\%)$ & 2.3 & 1.1 & 0.05 & 0.24 & 0.14 \\
$\mathrm{C} / \mathrm{N}$ & 15.2 & 24.3 & 14.5 & 10.7 & 12.0 \\
\hline \multicolumn{5}{c}{${ }^{\text {a }}$ Organic matter; ${ }^{\mathrm{b}}$ dissolved organic carbon. }
\end{tabular}

\subsection{Field Experiment}

A field experiment was conducted on the Muñovela experimental farm belonging to the Institute of Natural Resources and Agrobiology of Salamanca (IRNASA-CSIC), Spain. It was designed in triplicate on experimental plots $(9 \mathrm{~m} \times 9 \mathrm{~m})$, randomly distributed, with the following treatments: unamended soil (S), unamended soil with herbicides (S + H), SMS-amended soil (S + SMS) at a rate of $140 \mathrm{t} \mathrm{SMS} \mathrm{ha-1}$, SMS-amended soil with herbicides (S + SMS + H), GC-amended soil (S + GC) at a rate of $85 \mathrm{tGC} \mathrm{ha}{ }^{-1}$, and GC-amended soil with herbicides $(\mathrm{S}+\mathrm{GC}+\mathrm{H})$. The amount of organic amendments was adjusted to $34 \mathrm{t}$ of organic carbon (OC) ha ${ }^{-1}$ on a dry weight basis. SMS and GC were uniformly spread on a field with a tractor and then dug into the $20 \mathrm{~cm}$ topsoil with a rotavator. 
Topsoil samples $(0-10 \mathrm{~cm})$ were characterized after 30 days of SMS and GC application just before the herbicides were applied to replicate the initial state of the soil samples as faithfully as possible.

Herbicides were applied manually after winter wheat sowing in December 2016 as a water suspension using a backpack sprayer (10 L volume). The doses applied to the plots were five times the recommended agronomic application rates for chlorotoluron, flufenacet, and diflufenican $(15,5$, and $2.5 \mathrm{~kg}$ a.i. $\mathrm{ha}^{-1}$, respectively). The increase in the soil's capacity for adsorbing the herbicides after the addition an organic amendment supports the use of rates higher than those recommended to remain minimally phyto available and maintain the efficacy of the compounds against weeds [31]. No herbicide residues were detected in the field soil prior to the application of the herbicides. After herbicide application ( 0 days), and at 45, 145, 229 and 339 days after treatment, the samples of surface soil $(0-10 \mathrm{~cm})$ were collected to determine, in all treatments, residual amounts of herbicides, soil dehydrogenase activity (DHA), microbial biomass, and phylogenetic structure by phospholipid fatty acids (PLFAs) in all the treatments. Additionally, soil samples were collected 3 days before herbicide application ( -3 days) to determine the phylogenetic structure. A detailed description of the soil sampling procedure is included in Appendix A. Analytical methods to determine the residual concentration of herbicides, the soil DHA activity, the microbial biomass and specific PLFAs used as biomarkers to quantify the relative abundances of Gram-negative bacteria, Gram-positive bacteria, Actinobacteria, and fungi are included in Appendix B [21,32-34]. Rainfall and air temperature data were recorded throughout the experimental period (Figure A1). The average air temperature ranged from -3.8 to $27^{\circ} \mathrm{C}$, with a mean value of $13.1{ }^{\circ} \mathrm{C}$ over the experimental period. Accumulated precipitation at the end of the experimental period was $273.2 \mathrm{~mm}$, with the average intensity being $2.5 \mathrm{~mm} \mathrm{~h}^{-1}$.

\subsection{Statistical Analysis}

The normal distribution of data was checked using the Shapiro-Wilk test and the homogeneity of variance was checked using Levene's test. Data underwent two-way analysis of variance (ANOVA), with the main factors being soil treatments and sampling times. The Tukey post hoc test at $p<0.05$ was used to determine significant differences between means, and evaluate the effects of the different soil treatments and sampling times on the remaining amounts of herbicides in soils and on DHA, the total microbial biomass and the relative abundance of microorganism groups. Pearson correlation coefficients were determined between the remaining percentages of herbicides and DHA values. ANOVA and correlation analyses were carried out using the IBM SPSS Statistics v26 software package (IBM, New York, NY, USA). Principal component analysis (PCA) was performed with PAST v3.23 software (Øyvind Hammer, Oslo, Norway) [35] to determine the most meaningful variables and the global impact of the herbicides on soil microbial communities. Besides PCA, two-way PERMANOVA analysis was performed to determine the significance of herbicide application, sampling times, soil treatments, and their interactions.

\section{Results and Discussion}

\subsection{Herbicide Residues in Unamended and Amended Soils}

The herbicide concentrations determined in unamended and amended soils after their application ranged between 11.6 and 13.1, 4.11 and 5.08 and 2.24 and $2.81 \mu \mathrm{g} \mathrm{g}^{-1}$ dry soil for chlorotoluron, flufenacet, and diflufenican, respectively. These concentrations recorded at different times indicated a continuous degradation of chlortoluron and flufenacet in all the samples. However, the two-way ANOVA performed with time and soil management as factors for each herbicide separately indicated that this interaction was only significant for chlorotoluron $(p=0.000)$, with higher amounts in SMS-amended soils than in unamended ones, but there were no significant differences for flufenacet $(p=0.3322)$ (Table 3$)$. The results confirm that chlorotoluron dissipates faster than flufenacet in the same soils determined at laboratory scale [21]. Both herbicides persisted longer in amended soils due to their higher adsorption and lower bioavailability for degradation [36]. Diflufenican concentration 
decreased in S and S + GC after 45 days of treatment (Table 3), but no decrease was observed in S + SMS possibly due to different initial adsorption of diflufenican by the soils as reported previously [37]. However, no more significant decreases in concentrations were determined over time up to the end of experiment due to its high persistence [38]. Diflufenican was more persistent than flufenacet and chlorotoluron, and $>65 \%$ of the herbicide was found after 339 days of its application in the surface soils. The dissipation of chlorotoluron and flufenacet was almost complete at the last sampling time in the field experiment. At 339 days after herbicide application, residual concentrations of flufenacet $(<8 \%)$ were lower than those of chlorotoluron $(<15 \%)$ and diflufenican $(<70 \%)$.

Table 3. Remaining residues of chlorotoluron, flufenacet and diflufenican in unamended (S) and amended (S + SMS and S + GC) soils at different sampling times after application of the herbicides.

\begin{tabular}{cccccc}
\hline \multirow{2}{*}{ Herbicide/Soil } & \multicolumn{5}{c}{ Residual Herbicide $\left(\mu \mathrm{g}\right.$ Herbicide $\mathbf{g}^{-\mathbf{1}}$ Dry Soil) \pm SD $^{\mathbf{a}}$} \\
\cline { 2 - 6 } & 0 Days & 45 Days & 145 Days & 229 Days & 339 Days \\
\hline Chlorotoluron & & & & \\
S & $11.6 \pm 1.05 \mathrm{ab}$ & $7.53 \pm 0.46 \mathrm{c}$ & $2.53 \pm 0.20 \mathrm{de}$ & $1.44 \pm 0.20 \mathrm{ef}$ & $1.82 \pm 0.17 \mathrm{ef}$ \\
S + SMS & $13.1 \pm 0.77 \mathrm{a}$ & $11.0 \pm 0.28 \mathrm{~b}$ & $3.39 \pm 0.16 \mathrm{~d}$ & $1.12 \pm 0.02 \mathrm{ef}$ & $0.78 \pm 0.21 \mathrm{f}$ \\
S + GC & $11.8 \pm 1.20 \mathrm{ab}$ & $9.14 \pm 1.18 \mathrm{c}$ & $2.36 \pm 0.17 \mathrm{def}$ & $1.34 \pm 0.06 \mathrm{ef}$ & $1.04 \pm 0.03 \mathrm{ef}$ \\
Flufenacet & & & & & \\
S & $4.11 \pm 0.10 \mathrm{ab}$ & $3.46 \pm 0.12 \mathrm{bc}$ & $1.68 \pm 0.19 \mathrm{de}$ & $0.82 \pm 0.08 \mathrm{ef}$ & $0.29 \pm 0.06 \mathrm{f}$ \\
S + SMS & $5.08 \pm 1.05 \mathrm{a}$ & $4.47 \pm 0.30 \mathrm{ab}$ & $2.70 \pm 0.42 \mathrm{~cd}$ & $1.03 \pm 0.11 \mathrm{ef}$ & $0.40 \pm 0.02 \mathrm{f}$ \\
S + GC & $4.44 \pm 0.50 \mathrm{ab}$ & $3.94 \pm 0.56 \mathrm{ab}$ & $2.51 \pm 0.29 \mathrm{~cd}$ & $0.82 \pm 0.30 \mathrm{ef}$ & $0.12 \pm 0.03 \mathrm{f}$ \\
Diflufenican & & & & & \\
S & $2.24 \pm 0.27 \mathrm{ab}$ & $1.72 \pm 0.53 \mathrm{~b}$ & $1.62 \pm 0.24 \mathrm{~b}$ & $1.30 \pm 0.18 \mathrm{~b}$ & $1.43 \pm 0.31 \mathrm{~b}$ \\
S + SMS & $2.81 \pm 0.64 \mathrm{a}$ & $2.03 \pm 0.22 \mathrm{ab}$ & $2.26 \pm 0.53 \mathrm{ab}$ & $2.00 \pm 0.34 \mathrm{ab}$ & $1.95 \pm 0.17 \mathrm{ab}$ \\
S + GC & $2.27 \pm 0.31 \mathrm{ab}$ & $1.45 \pm 0.26 \mathrm{~b}$ & $1.58 \pm 0.07 \mathrm{~b}$ & $1.48 \pm 0.14 \mathrm{~b}$ & $1.53 \pm 0.21 \mathrm{~b}$ \\
\hline
\end{tabular}

a Standard deviation of the mean. For each compound separately, the values followed by the same letter in lines and columns were not significantly different according to the Tukey post hoc test at a confidence level of $95 \%$.

\subsection{Soil Dehydrogenase Activity (DHA)}

The effect of organic amendments and herbicides on overall soil microbial activity was assessed by determining the soil DHA at different sampling times during the assay (Figure 1). Soil DHA values were lower in unamended soils and those treated with herbicides compared to their respective controls $(p \leq 0.05)$.

A progressive decrease in DHA values was observed in $\mathrm{S}+\mathrm{H}$ throughout the assay compared to the soil control, mainly at the last sampling times (145-339 days after herbicide application) $(p<0.05)$. Therefore, the combination of the three herbicides had a negative impact on soil microbial activity, with a significant relationship $(r=0.94, p<0.05)$ between residual amounts of the three herbicides and DHA values in unamended soil, indicating that DHA decreased simultaneously with the dissipation of the herbicides applied. Consequently, DHA recovery did not occur over time, possibly due to the toxicity of the most persistent herbicide residues. In previous work, authors have reported that soil DHA increased by $4.21 \%$ when treated with flufenacet + isoxaflutole at the recommended dose $\left(0.250 \mathrm{mg} \mathrm{kg}^{-1}\right)$ compared to the soil control [7]. However, when applied at the highest dose (40 $\mathrm{m} \mathrm{kg}^{-1}$ ), it inhibited the DHA, which could be due to the toxic effect of the herbicide flufenacet with a higher $\mathrm{DT}_{50}$ value than isoxaflutole on soil microorganisms with enzymatic activity [27]. Diflufenican, with a long persistence in this soil, could also be responsible for the decrease in DHA in $\mathrm{S}+\mathrm{H}$.

The application of organic amendments to soil promoted DHA with respect to unamended soil $(p \leq 0.05)$. This effect has previously been reported by other authors for soils amended with different organic residues, being explained as the higher available nutrients and OC contents of amended soils $[6,11,39]$. The use of organic amendments had a certain buffer effect on DHA after herbicide application because values of this microbial activity were more constant during the assay in S + SMS $+\mathrm{H}$ and $\mathrm{S}+\mathrm{GC}+\mathrm{H}$. This buffer effect might be due to chemical binding of the herbicides to the matrix, or due to altered microbial activities in the presence of co-substrates. Despite this positive effect, 
the buffer capacity of the organic amendments, SMS and GC, was not enough to fully neutralize the negative effect of the herbicide mixture. The soil DHA of S + SMS + H and S + GC + H was significantly lower than the DHA of S + SMS and S + GC during the assay, although the values were constant over time (Figure 1). Significant interaction between soil treatment and time was detected $(p<0.001)$. No significant changes in DHA were observed simultaneously to the dissipation of herbicides applied as observed in $\mathrm{S}+\mathrm{H}$, and a non-significant relationship was found between herbicide residues and DHA values in the amended soils. This was probably due to the combination of herbicides applied with different adsorption and bioavailability rates in the amended soils, and the long persistence of some of them to produce more toxic effects on soil microbial biomass and activity than the single application of individual compounds [3,13]. Previous studies have reported this trend for one of the herbicides used here, namely, diflufenican, which mixed with glyphosate or with mesosulfuron-methyl and iodosulfuron methyl-sodium decreased DHA and other enzymatic activities [18,26].

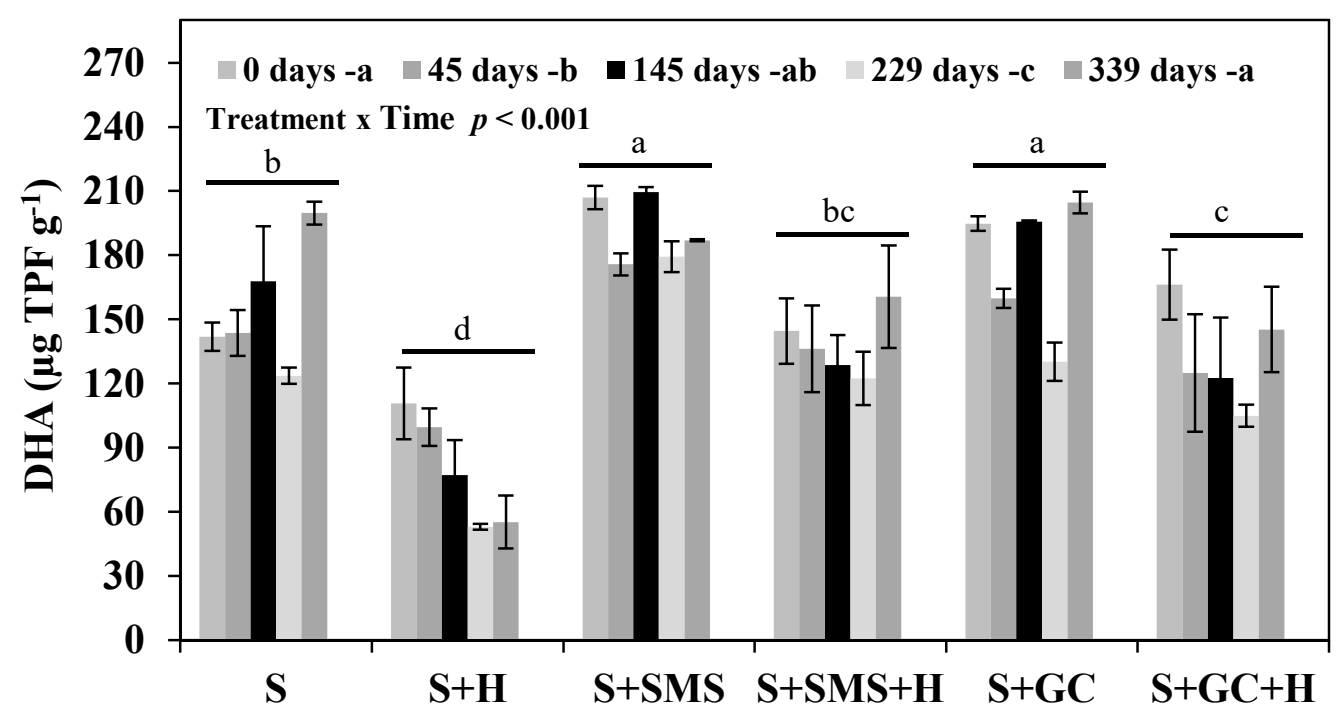

Figure 1. Dehydrogenase activity (DHA) for unamended soil (S) and soils amended with spent mushroom substrate (SMS) or green compost (GC) in the absence or presence of herbicides $(\mathrm{H})$. Data present the mean \pm standard deviation of three replicated plots. Letters at the legend provide the dose main effect groupings according to the Tukey post hoc test $(p \leq 0.05)$. Soil treatments designed by different letters are significantly different (Tukey post hoc test; $p \leq 0.05$ ).

The soil DHA values of the unamended soil and the SMS- and GC-amended soils without herbicides tended to remain constant during the assay period (Figure 1). This also occurred in the soils with herbicides, with the exception of $\mathrm{S}+\mathrm{H}$, indicating that soil microbiota retained their functional activity over time. In the SMS- and GC-amended soils with herbicides, amendments may minimize the impact of herbicides on soil microbial activity compared to unamended soil $(\mathrm{S}+\mathrm{H})$. The herbicides studied were hydrophobic compounds, and adsorption increased in the amended soils $[21,36]$, hampering their bioavailability and their possible use as a carbon source by microorganisms for increasing microbial activity. This effect has also been reported for prosulfocarb and triasulfuron when applied in field plots with GC-amended soils [13,19].

\subsection{Soil Microbial Community}

Microbial biomass and structure were monitored in the unamended and amended soils during the assay period. The total microbial population was expressed as the sum of PLFAs (Figure 2), and the structure was shown by the relative abundance of PLFAs that specifically diagnose Gram-negative and Gram-positive bacteria, Actinobacteria, and fungi (Figure 3). 


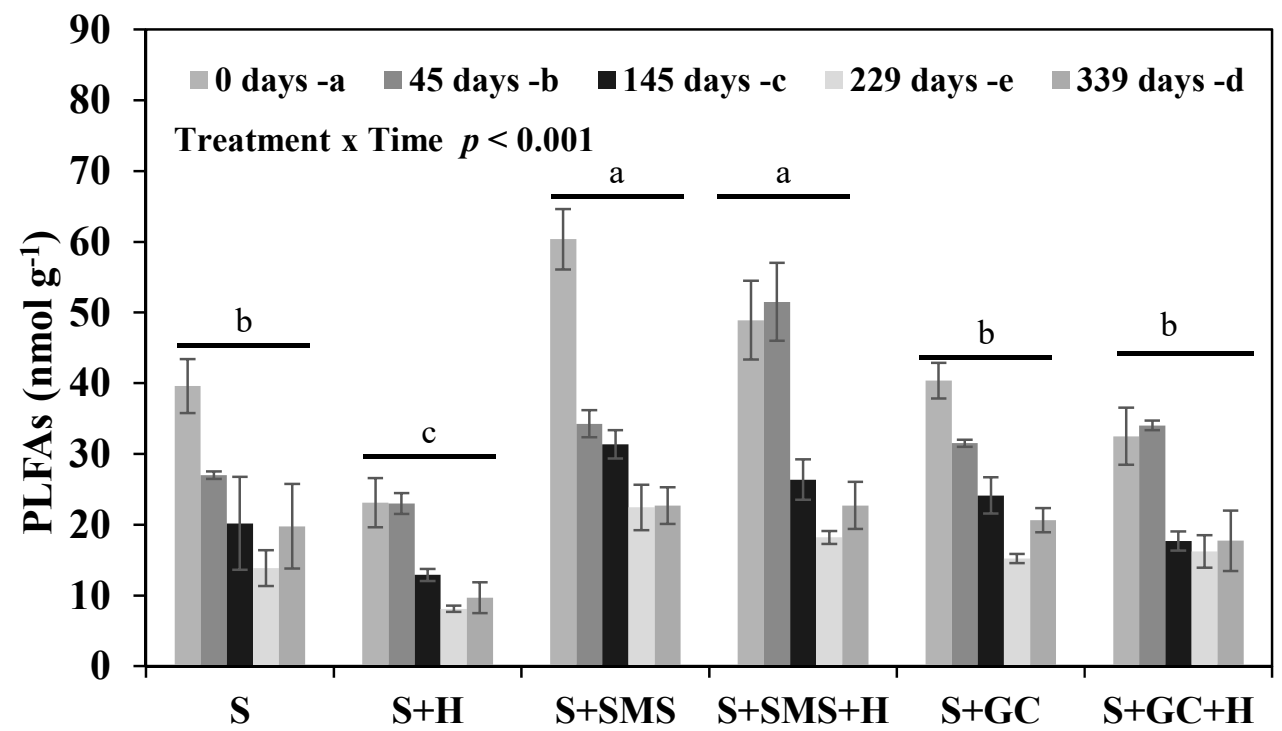

Figure 2. Total microbial population (nmol PLFAs $\mathrm{g}^{-1}$ ) for unamended soil (S) and soils amended with spent mushroom substrate (SMS) or green compost (GC) in the absence or presence of herbicides $(\mathrm{H})$. Data present the mean \pm standard deviation of three replicated plots. Letters at the legend provide the dose main effect groupings according to the Tukey post hoc test $(p \leq 0.05)$. Soil treatments designed by different letters are significantly different (Tukey post hoc test; $p \leq 0.05$ ).

The concentrations of PLFAs in the unamended soils during the assay ranged between 39.6 and $8.11 \mathrm{nmol} \mathrm{g}^{-1}$. The SMS- and GC-amended soils recorded higher values of PLFAs $(p \leq 0.05)$ with concentration ranges of 63.9-18.2 and 40.9-15.2 $\mathrm{nmol} \mathrm{g}^{-1}$, respectively. These PLFA concentrations provide information on the microbial community's total biomass. They significantly decreased over time $(p \leq 0.05)$ regardless of organic amendment and/or herbicide application, and no recovery effect was observed as occurred with other organic amendments [39] and/or herbicides [13].

The mixture of herbicides produced only a significant decrease $(p \leq 0.05)$ in the microbial population for $\mathrm{S}+\mathrm{H}$ compared to the soil control, which is consistent with the decrease in DHA values observed (Figure 1). This change corresponds to a significant reduction in the total concentration of bacterial PLFAs in S + H (data not shown). In addition, the ratio of Gram-negative/Gram-positive bacteria was modified by herbicide application. The relative abundance of Gram-positive bacteria was negatively impacted by herbicide application, whereas the relative abundance of Gram-negative bacteria increased $(p<0.05)$ (Figure 3). Decreases in the Gram-positive bacteria more sensitive to environmental stresses than Gram-negative bacteria were also observed after the application of other pesticides, including herbicides such as acetochlor [40] and fomesafen [41] or insecticides such as teflubenzuron [42], in unamended soil. A previous study reported the toxic effects of both diflufenican and diflufenican + glyphosate on soil microbial biomass in two unamended soils [18]. No significant effects by herbicide application were detected for Actinobacteria or fungi in unamended soil (Figure 3). 

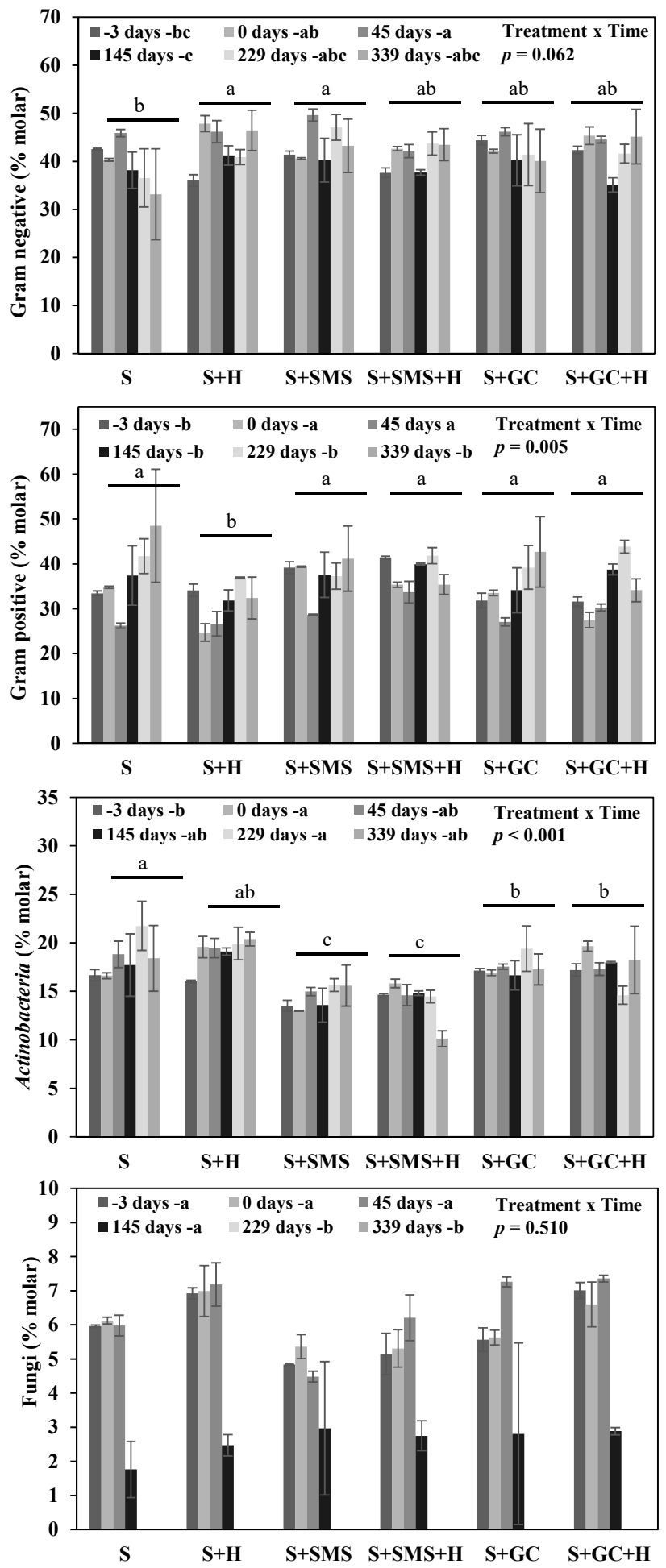

Figure 3. Relative abundance (\% mol) of PLFAs specifically diagnostic of Gram-negative and Gram-positive bacteria, Actinobacteria and fungi in unamended soil (S) and soils amended with spent mushroom substrate (SMS) or green compost (GC) in the absence or presence of herbicides (H). Data present the mean \pm standard deviation of three replicated plots. Letters at the legend provide the dose main effect groupings according to the Tukey post hoc test $(p \leq 0.05)$. Soil treatments designed by different letters are significantly different (Tukey post hoc test; $p \leq 0.05$ ). Lack of letters indicates no significant differences. 
In contrast to the unamended soil, there were no significant differences during the assay in soil microbial biomass between SMS- or GC-amended soils with and without herbicides $(p>0.05)$ (Figure 2). Residual amounts of the three herbicides studied were detected at the experiment's last sampling time (Table 3), which means SMS and GC buffered the herbicides' bioavailability during their dissipation or their toxic effects on total microbial population. As indicated for the DHA changes, this may be due to the combination of certain positive properties of the organic amendments, such as the adsorption capacity of herbicides, which minimize their bioavailability, an increased input of microorganisms and improve the soil's nutrient status and physical properties [15,43,44]. In SMSor GC-amended soils, the increase in soil microbial biomass at day 0 might be due to the input of organic matter born microorganisms, but there was a decrease in soil microbial biomass from day 45 (Figure 2). No significant differences in the total concentration of bacterial and/or fungal PLFAs were found in S + SMS or S + GC in the presence of herbicides (data not shown). Complex interactions of different factors related to pesticide properties and the microbial community have been reported to explain the microbial community's response to pesticides in some biobed organic substrates [45]. In the present work, the application of herbicides did not produce significant effects in the relative abundance of Gram-negative and Gram-positive bacteria, Actinobacteria, and fungi in SMS- and GC-amended soils, respectively (Figure 3). However, the application of SMS reduced the relative abundance of Actinobacteria with respect to unamended or GC-amended soils. Because of the assay's long duration, modifications of the microbial structure were to be expected. The modifications of soil moisture and temperature over the year were probably responsible for the soil microbial shift over the 339 days of assay. Moreover, over this time, it should be noted that the specific PLFAs of fungi (18:2 w6cis) were not detected after 145 days (samples at 229 and 339 days) because values were below the detection limit, irrespective of the herbicides or organic amendments applied.

Changes in the soil microbial structure in response to herbicide application in the unamended soil and in the SMS- and GC-amended soils were studied through the PCA of the relative abundance of Gram-negative and Gram-positive bacteria, Actinobacteria, and fungi (Figure 4). According to the PERMANOVA test (Table 4), the global microbial structure was significantly impacted by herbicide application and sampling time $(p<0.005)$. Therefore, the simultaneous application of chlorotoluron, flufenacet, and diflufenican led to a significant shift in the soil microbial structure compared to no herbicide application. Microbial adaptation is a well-known phenomenon which allows bacteria to withstand exposure to a toxicant. By means of physiological acclimation or genetic inheritance, it allows selecting tolerant populations that can cope better with xenobiotics [46]. Kucharski et al. has reported microorganism changes depending on the herbicide dose and soil incubation time, and the results indicate that the application of flufenacet + isoxaflutole could influence the structure of microorganism communities [7]. Similarly, Tomkiel et al. have reported that soil contaminated by a mixture of flufenacet and isoxaflutole usually has a negative impact on soil-dwelling microorganisms, which might be due to these substances' different half-lives [27].

$\mathrm{S}+\mathrm{H}$ samples are located in the upper right zone of the PCA related to Gram-negative bacteria and Actinobacteria. In contrast, S samples were widely dispersed in the PCA. S samples of -3 and 0 days recorded low values of PC1 that denoted a certain equilibrium between Gram-negative and Gram-positive bacteria. In contrast, these samples were clearly located in the negative values of PC2, and therefore had a weak relationship with the high abundance of Actinobacteria, and some relationship with the high abundance of fungi. The application of herbicides in $\mathrm{S}+\mathrm{H}$ prompted a clear shift of the microbial structure towards the higher relative abundance of Gram-negative bacteria than the $S$ treatment at 0 days. The microbial structure's evolution over time in the $S$ and $S+H$ samples was similar, moving towards a closer relationship with Gram-positive bacteria and Actinobacteria at the last sampling times (229-339 days). Despite this similar trend over time, the $S$ samples at the last sampling time recorded lower values in $\mathrm{PC} 1$ than the $\mathrm{S}+\mathrm{H}$ samples. Hence, $\mathrm{S}$ samples were more closely related to a high relative abundance of Gram-positive bacteria than $\mathrm{S}+\mathrm{H}$ samples (Figure 4). 

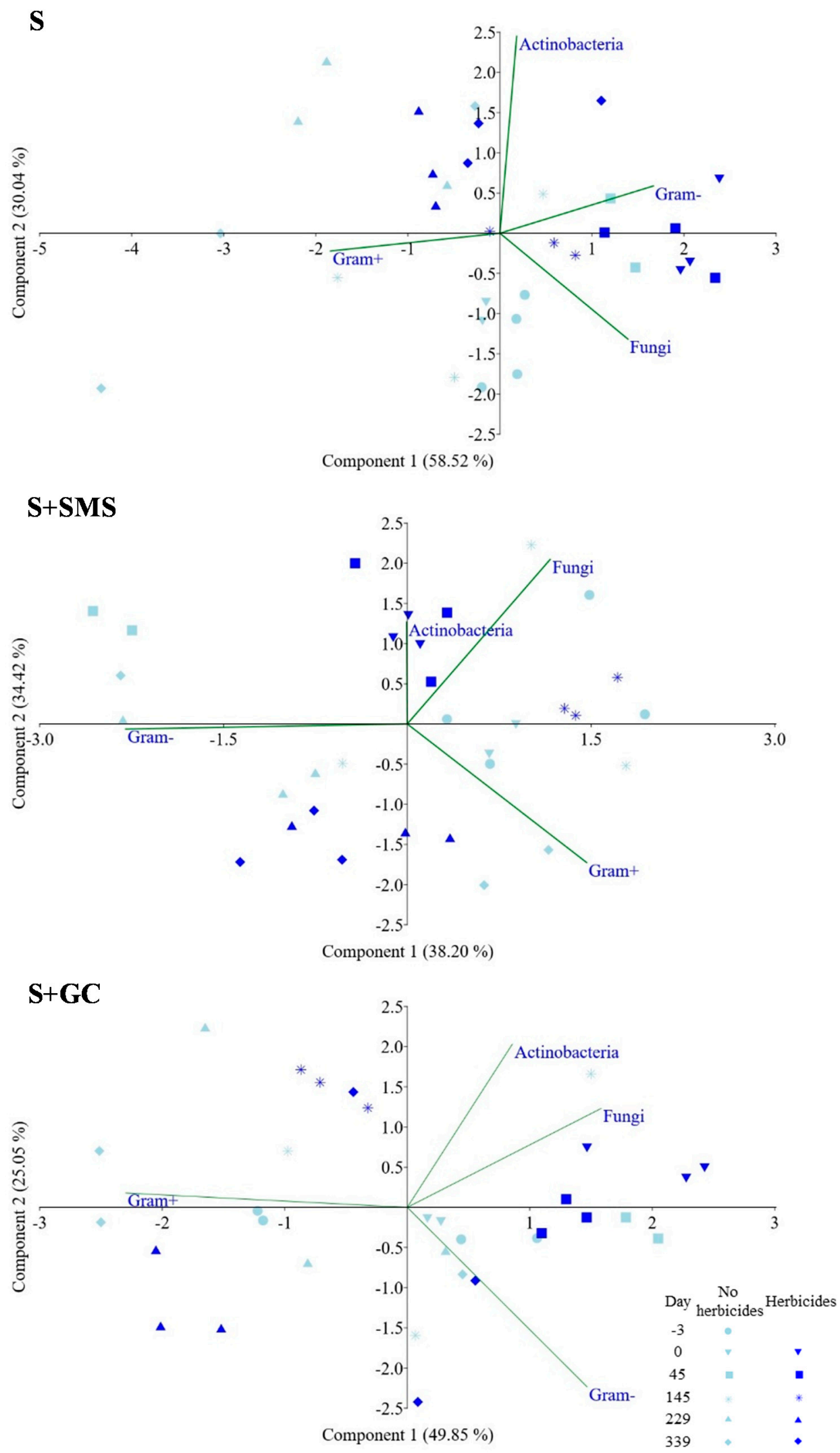

Figure 4. Principal components analysis (PCA) of unamended (S) and amended soils (S + SMS and $S+$ GC) showing loading scores for Gram- and Gram+ bacteria, Actinobacteria and fungi, and the scores of sampling times on the two main components. The application of herbicides is denoted by dark blue, the non-application of herbicides by light blue. Percent variability explained by each principal component is shown in parentheses after each axis legend. 
Table 4. Results of PERMANOVA of the effect of herbicides $(\mathrm{H})$ application, sampling time $(\mathrm{T})$, soil treatment (STr) and their interaction on the relative abundance $\left(\mathrm{nmol} \mathrm{g}^{-1}\right)$ of PLFAs specific for Gram-positive and -negative bacteria, Actinobacteria and fungi in unamended (S) and amended $(\mathrm{S}+\mathrm{SMS}$ and $\mathrm{S}+\mathrm{GC})$ soils.

\begin{tabular}{ccc}
\hline Variable & F-Value & $p$-Value \\
\hline S & & \\
Herbicide & 7.112 & $\mathbf{0 . 0 0 5 0}$ \\
Time & 13.23 & $\mathbf{0 . 0 0 0 1}$ \\
$\mathrm{H} \times \mathrm{T}$ & -1.517 & 0.9356 \\
\hline $\mathrm{S}+\mathrm{SMS}$ & & \\
Herbicide & 0.792 & 0.3802 \\
Time & 36.07 & $\mathbf{0 . 0 0 0 1}$ \\
$\mathrm{H} \times \mathrm{T}$ & 0.449 & $\mathbf{0 . 0 0 1 9}$ \\
\hline $\mathrm{S}+\mathrm{GC}$ & & \\
Herbicide & 1.012 & 0.3193 \\
Time & 25.41 & $\mathbf{0 . 0 0 0 1}$ \\
$\mathrm{H} \times \mathrm{T}$ & 0.394 & $\mathbf{0 . 0 0 1 4}$ \\
\hline Global & & \\
Herbicide & 6.373 & $\mathbf{0 . 0 0 3 9}$ \\
Time & 31.63 & $\mathbf{0 . 0 0 0 1}$ \\
\hline STr & 5.777 & $\mathbf{0 . 0 0 1 0}$ \\
$\mathrm{H} \times \mathrm{T}$ & -2.051 & 0.3472 \\
$\mathrm{H} \times \mathrm{STr}$ & 1.279 & $\mathbf{0 . 0 2 1 5}$ \\
$\mathrm{T} \times \mathrm{STr}$ & 0.717 & $\mathbf{0 . 0 4 5 2}$ \\
\hline & &
\end{tabular}

The presence of herbicides promoted the relative abundance of Actinobacteria at the final sampling time. Actinobacteria is one of the world's most abundant and ubiquitous phylotypes of soil bacteria [28], whereby its versatility for colonizing a wide variety of soils and environments could be responsible for its resistance towards herbicides. Kalia and Gosal have reported that fungi and Actinobacteria are characterized by the highest capabilities for metabolizing xenobiotics [47]. Baćmaga et al. have reported that the diflufenican + mesosulfuron-methyl + iodosulfuron-methyl-sodium mixture has a generally stimulating effect on Actinobacteria, among others, and inhibits the proliferation of fungi [26]. García-Delgado et al. have reported a positive relationship between herbicide degradation and Actinobacteria, and a negative relationship between fungi and residual herbicides, as confirmation of this work [19]. Likewise, Petric et al. have reported Actinobacteria to be a nicosulfuron-tolerant bacteria [46].

The application of herbicides did not produce significant effects according to the PERMANOVA test of SMS- and GC-amended soils (Table 4). In fact, the PCA profiles of samples with and without herbicides from the SMS- and GC-amended soils clearly overlapped (Figure 4). However, the significant interaction $\mathrm{H} \times \mathrm{T}$ in SMS- and GC-amended soils denoted isolated differences between samples with and without herbicide application. The interaction in SMS-amended soils was at 45 days when samples without herbicide were more related to Gram-negative bacteria than samples with herbicide application. The interaction in GC-amended soil was at 339 days when samples without herbicides were more related to Gram-positive bacteria than samples with herbicide application. However, these changes of trend are not crucial from the agricultural management point of view because they are temporary. Therefore, in contrast to the unamended soil, the simultaneous application of chlorotoluron, flufenacet, and diflufenican was not responsible for the soil microbial shift. Once again, the buffer capacity of organic amendments to minimize the toxic effects of herbicides on the soil microbial community has been confirmed in this work. Previous studies have reported this positive effect of organic amendments, but the buffer capacity of organic amendments to detoxify herbicides was limited, and mixtures of other herbicides had an impact on the soil microbial structure $[13,19]$. Hence, the interaction between 
herbicides and organic amendments seems a key factor to determine the latter's ability to buffer the negative effects of herbicides on the soil microbial structure. This interaction could be enhanced by the low water solubility of chlorotoluron, flufenacet, and diflufenican (Table 1), which could enhance the adsorption by the amendments' OM and minimize their bioavailability. Marín-Benito et al. have determined the sorption coefficients $(\mathrm{Kd})$ and the degradation kinetics of chlorotoluron and flufenacet by unamended and SMS- and GC-amended soils similar to the ones used here [21]. The application of SMS and GC produced a significant increase in the Kd values of these herbicides compared to unamended soil, and a decrease in the degradation rates of both herbicides due to their higher sorption and lower bioavailability for degrading.

The microbial shift in SMS- and GC-amended soils in response to herbicides during the assay was due to a temporal drift (Table 4). The SMS-amended soils samples treated with herbicides at 0 days were related to the high relative abundance of Actinobacteria and fungi and were clearly less related to Gram-negative bacteria. At the last sampling times, 229 and 339 days, the microbial structure shifted towards Gram-positive and Gram-negative bacteria in detriment to Actinobacteria and fungi. This behavior was also observed in results presented in Figure 3, where specific PLFAs of fungi were not detected. The microbial structure of GC-amended soils at 0 and 45 days after herbicide application was characterized by a high relationship with the positive zone of PC1 (Actinobacteria, fungi and Gram-negative bacteria) and clear poor relationship with Gram-positive bacteria. During the assay, the microbial structure shifted towards the negative zone of $P C 1$, increasing the weight of Gram-positive bacteria in the microbial equilibrium. The interaction herbicide $x$ time could be reflected in the PCA in the long term due to the high distance between S + GC and S + GC + H samples at 229 and 339 days.

\section{Conclusions}

The simultaneous application of GC or SMS as organic amendments and the herbicides chlorotoluron, flufenacet, and diflufenican in an agricultural soil at field scale had little effect on the biological parameters that were tested in the soil microbial community. In the amended soils, total soil microbial biomass decreased over time regardless of the organic amendment or the herbicides, and microbial activity (DHA) was constant, although it decreased in the presence of herbicides. In contrast, a significant decrease in microbial activity and a significant modification of the microbial structure were observed in the unamended soil treated with the herbicides. The organic amendments were useful for buffering the effects of herbicides on soil microbial biomass and activity, and for reducing the shift in the soil microbial composition. However, despite its buffer effect on the microbiota with respect to herbicides, the combined application of these herbicides in the amended soils prompted a decrease in soil microbial activity compared to the control soils. Consequently, the use of these organic residues is suggested for reducing the impact of herbicides on soil microbiota, and furthermore for decreasing the risk of pollution by herbicide leaching. However, there is a need to evaluate the impact the following have on soil microbial communities: individual herbicides, the major degradation products of herbicides in soil, and the additives (solvents and surfactants) present in commercial formulations of herbicides.

Author Contributions: Conceptualization, M.J.S.-M. and M.S.R.-C.; methodology, C.G.-D., M.J.C. and J.M.M.-B.; validation, C.G.-D. and M.J.S.-M.; formal analysis, C.G.-D. and M.J.S.-M.; investigation, M.J.C., C.G.-D. and J.M.M.-B.; resources, M.S.R.-C. and M.J.S.-M.; writing—original draft preparation, C.G.-D., M.J.C. and M.S.R.-C.; writing—review and editing, M.J.C., C.G.-D., M.S.R.-C., J.M.M.-B. and M.J.S.-M.; visualization, M.J.C. and C.G.-D.; supervision, M.S.R.-C., J.M.M.-B. and M.J.S.-M.; project administration, M.J.S.-M.; funding acquisition, M.J.S.-M. All authors have read and agreed to the published version of the manuscript.

Funding: This research was funded by MINECO/FEDER UE, grant number AGL2015-69485-R. M.J.C. thanks "Consejería de Educación, Junta de Castilla y León" for her predoctoral contract co-funded by the European Social Fund. C.G.-D. and J.M.M.-B. thank MINECO for their Juan de la Cierva-Formación (JCFI-2015-23543) and Juan de la Cierva-Incorporación (IJCI-2014-19538) contracts, respectively. 
Acknowledgments: The authors thank J.M. Igual for his collaboration in the PFLA analysis and J.M. Ordax for his technical assistance.

Conflicts of Interest: The authors declare no conflict of interest. The funders had no role in the design of the study; in the collection, analyses, or interpretation of data; in the writing of the manuscript, or in the decision to publish the results.

\section{Appendix A. Analysis of Herbicides}

At each sampling time, five $0-10 \mathrm{~cm}$ soil subsamples were randomly collected in each plot. Representative average soil samples of each plot were obtained by mixing the five subsamples. Composite samples were put into plastic bags and transported in portable refrigerators to the laboratory, where they were homogenized and sieved $(<2 \mathrm{~mm})$ for their analysis.

Triplicate subsamples of moist soil ( $6 \mathrm{~g})$ were extracted from each plot with acetonitrile $(12 \mathrm{~mL})$ to determine herbicide residues. The samples were sonicated for $1 \mathrm{~h}$, shaken at $20^{\circ} \mathrm{C}$ for $24 \mathrm{~h}$, and then centrifuged at $3000 \mathrm{rpm}$ for $15 \mathrm{~min}$. The extracts were filtered in a GHP Acrodisc filter (Waters Corporation) to remove particles $>0.45 \mu \mathrm{m}$, and then evaporated until dryness at $25{ }^{\circ} \mathrm{C}$ under a nitrogen stream using an EVA- EC2-L evaporator (VLM GmbH, Bielefeld, Germany). The residue was dissolved in $0.75 \mathrm{~mL}$ of acetonitrile and transferred to a HPLC glass vial for analysis. Herbicides were quantified by high-performance liquid chromatography/diode array detector/mass spectrometry (HPLC-DAD-MS) (Waters Assoc., Milford, USA). A detailed description of the analytical method is included in [21].

\section{Appendix B. Soil Biochemical Properties and PLFA Analysis}

Soil DHA was determined by the Tabatabai method [33]. Briefly, $6 \mathrm{~g}$ of fresh soil was mixed with $60 \mathrm{mg}$ of calcium carbonate and $1 \mathrm{~mL}$ of 3\% 2,3,5-triphenyltetrazolium chloride and $2.5 \mathrm{~mL}$ of ultrapure water. The reaction mixture was incubated at $37^{\circ} \mathrm{C}$ for $24 \mathrm{~h}$ in the dark. At the end of incubation, the 1,3,5-triphenylformazan (TPF) was extracted with $7 \mathrm{~mL}$ of methanol, centrifuged (3000 rpm, $10 \mathrm{~min}$ ), and extracted twice more. The three fractions were mixed and diluted to $25 \mathrm{~mL}$ with methanol. The absorbance of the supernatant was measured in a spectrophotometer at $485 \mathrm{~nm}$. The results were expressed as $\mu \mathrm{g} \mathrm{TPF} \mathrm{g}^{-1}$ dry soil.

The soil samples' microbial biomass and structure were determined using phospholipid fatty acid (PLFA) analysis [32]. Lyophilized soil samples were extracted by sonication with a one-phase chloroform-methanol-phosphate buffer solvent. The samples were then purified by solid-phase extraction (SPE), and polar lipids were transesterified with methanol-KOH. Finally, hexane extracts containing the resultant fatty acid methyl esters (FAMEs) were analyzed by gas chromatography. Quantification was performed using an Agilent 7890 gas chromatograph (Agilent Technologies, Wilmington, DE, USA) equipped with a 25 -mUltra 2 (5\% phenyl)-methylpolysiloxane column (J\&W Scientific, Folsom, CA, USA) and a flame ionization detector. PLFAs were identified using bacterial fatty acid standards and software from the Microbial Identification System (Microbial ID, Inc., Newark, DE, USA). Nonadecanoic acid (19:0) was used as an internal standard for the quantitative determination of PLFAs. The total microbial biomass was estimated by the total sum of PLFAs and expressed as nmol g-1. Specific PLFAs [34] were used as biomarkers to quantify the relative abundances of Gram-negative bacteria (monounsaturated fatty acids and cyclopropyl 17:0) and Gram-positive bacteria (iso and anteiso saturated branched chain fatty acids), Actinobacteria (10-methyl fatty acids), and fungi (18:2 w6 cis and 16:1w5). 


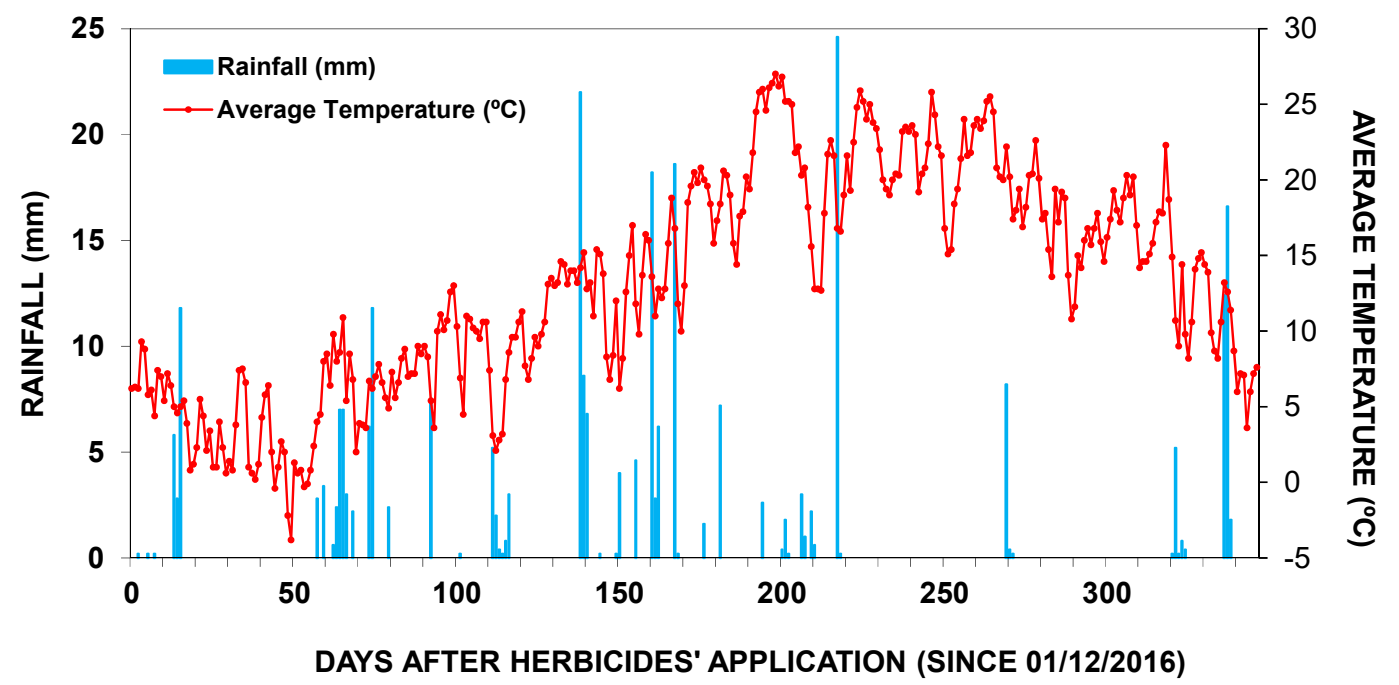

Figure A1. Rainfall and average temperature monitored over the experimental period.

\section{References}

1. Imfeld, G.; Vuilleumier, S. Measuring the effects of pesticides on bacterial communities in soil: A critical review. Eur. J. Soil Boil. 2012, 49, 22-30. [CrossRef]

2. Thiour-Mauprivez, C.; Martin-Laurent, F.; Calvayrac, C.; Barthelmebs, L. Effects of herbicide on non-target microorganisms: Towards a new class of biomarkers? Sci. Total. Environ. 2019, 684, 314-325. [CrossRef]

3. Pampulha, M.E.; Oliveira, A. Impact of an Herbicide Combination of Bromoxynil and Prosulfuron on Soil Microorganisms. Curr. Microbiol. 2006, 53, 238-243. [CrossRef] [PubMed]

4. Varjani, S.; Kumar, G.; Rene, E.R. Developments in biochar application for pesticide remediation: Current knowledge and future research directions. J. Environ. Manag. 2019, 232, 505-513. [CrossRef] [PubMed]

5. Lo, C.-C. Effect of pesticides on soil microbial community. J. Environ. Sci. Health Part B 2010, 45, 348-359. [CrossRef]

6. Rodríguez-Morgado, B.; Gómez, I.; Parrado, J.; Tejada, M. Behaviour of oxyfluorfen in soils amended with edaphic biostimulants/biofertilizers obtained from sewage sludge and chicken feathers. Effects on soil biological properties. Environ. Sci. Pollut. Res. 2014, 21, 11027-11035. [CrossRef]

7. Kucharski, J.; Tomkiel, M.; Baćmaga, M.; Borowik, A.; Wyszkowska, J. Enzyme activity and microorganisms diversity in soil contaminated with the Boreal 58 WG herbicide. J. Environ. Sci. Health Part B 2016, 51, 446-454. [CrossRef] [PubMed]

8. Medina, E.; Paredes, C.; Bustamante, M.A.; Moral, R.; Moreno-Caselles, J. Relationships between soil physico-chemical, chemical and biological properties in a soil amended with spent mushroom substrate. Geoderma 2012, 173, 152-161. [CrossRef]

9. Marín-Benito, J.M.; Sánchez-Martín, M.J.; Rodríguez-Cruz, M.S. Impact of Spent Mushroom Substrates on the Fate of Pesticides in Soil, and Their Use for Preventing and/or Controlling Soil and Water Contamination: A Review. Toxics 2016, 4, 17. [CrossRef] [PubMed]

10. Galán-Pérez, J.A.; Peña, A. Conditioning of a Calcaric Soil with Biosolid and Compost Under Laboratory Conditions: Exploration of Soil Property Evolution. Pedosphere 2019, 29, 266-272. [CrossRef]

11. Rodríguez-Liébana, J.A.; ElGouzi, S.; Mingorance, M.D.; Castillo, A.; Peña, A. Irrigation of a Mediterranean soil under field conditions with urban wastewater: Effect on pesticide behaviour. Agric. Ecosyst. Environ. 2014, 185, 176-185. [CrossRef]

12. Pérez-Piqueres, A.; Edel-Hermann, V.; Alabouvette, C.; Steinberg, C. Response of soil microbial communities to compost amendments. Soil Boil. Biochem. 2006, 38, 460-470. [CrossRef]

13. García-Delgado, C.; Barba-Vicente, V.; Marín-Benito, J.M.; Igual, J.M.; Sánchez-Martín, M.; Rodríguez-Cruz, M.S. Simultaneous application of two herbicides and green compost in a field experiment: Implications on soil microbial community. Appl. Soil Ecol. 2018, 127, 30-40. [CrossRef] 
14. Álvarez-Martín, A.; Hilton, S.; Bending, G.D.; Rodríguez-Cruz, M.S.; Sánchez-Martín, M.J. Changes in activity and structure of the soil microbial community after application of azoxystrobin or pirimicarb and an organic amendment to an agricultural soil. Appl. Soil Ecol. 2016, 106, 47-57. [CrossRef]

15. Marín-Benito, J.M.; Barba, V.; Ordax, J.; Andrades, M.; Sánchez-Martín, M.; Rodríguez-Cruz, M.S. Application of green compost as amendment in an agricultural soil: Effect on the behaviour of triasulfuron and prosulfocarb under field conditions. J. Environ. Manag. 2018, 207, 180-191. [CrossRef]

16. Cabrera, A.; Cox, L.; Spokas, K.A.; Hermosín, M.D.C.; Cornejo, J.; Koskinen, W. Influence of biochar amendments on the sorption-desorption of aminocyclopyrachlor, bentazone and pyraclostrobin pesticides to an agricultural soil. Sci. Total. Environ. 2014, 470, 438-443. [CrossRef]

17. Schloter, M.; Dilly, O.; Munch, J. Indicators for evaluating soil quality. Agric. Ecosyst. Environ. 2003, 98, 255-262. [CrossRef]

18. Tejada, M. Evolution of soil biological properties after addition of glyphosate, diflufenican and glyphosate+diflufenican herbicides. Chemosphere 2009, 76, 365-373. [CrossRef]

19. García-Delgado, C.; Barba-Vicente, V.; Marín-Benito, J.M.; Igual, J.M.; Sánchez-Martín, M.J.; Rodríguez-Cruz, M.S. Influence of different agricultural management practices on soil microbial community over dissipation time of two herbicides. Sci. Total. Environ. 2019, 646, 1478-1488. [CrossRef]

20. Lewis, K.; Green, A. The Pesticide Properties DataBase. Chem. Int. 2011, 33. [CrossRef]

21. Marín-Benito, J.M.; Carpio, M.J.; Sánchez-Martín, M.J.; Rodríguez-Cruz, M.S. Previous degradation study of two herbicides to simulate their fate in a sandy loam soil: Effect of the temperature and the organic amendments. Sci. Total. Environ. 2019, 653, 1301-1310. [CrossRef] [PubMed]

22. Saleh, O.; Pagel, H.; Enowashu, E.; Devers, M.; Martin-Laurent, F.; Streck, T.; Kandeler, E.; Poll, C. Evidence for the importance of litter as a co-substrate for MCPA dissipation in an agricultural soil. Environ. Sci. Pollut. Res. 2015, 23, 4164-4175. [CrossRef] [PubMed]

23. Cheng, J.; Lee, X.; Gao, W.; Chen, Y.; Pan, W.; Tang, Y. Effect of biochar on the bioavailability of difenoconazole and microbial community composition in a pesticide-contaminated soil. Appl. Soil Ecol. 2017, 121, 185-192. [CrossRef]

24. Juan, E.P.; Marín-Benito, J.M.; Sánchez-Martín, M.J.; Rodríguez-Cruz, M.S. Dissipation of herbicides after repeated application in soils amended with green compost and sewage sludge. J. Environ. Manag. 2018, 223, 1068-1077. [CrossRef] [PubMed]

25. Rodríguez-Cruz, M.S.; Pose-Juan, E.; Marín-Benito, J.M.; Igual, J.M.; Sánchez-Martín, M.J. Pethoxamid dissipation and microbial activity and structure in an agricultural soil: Effect of herbicide rate and organic residues. Appl. Soil Ecol. 2019, 140, 135-143. [CrossRef]

26. Baćmaga, M.; Borowik, A.; Kucharski, J.; Tomkiel, M.; Wyszkowska, J. Microbial and enzymatic activity of soil contaminated with a mixture of diflufenican + mesosulfuron-methyl + iodosulfuron-methyl-sodium. Environ. Sci. Pollut. Res. 2014, 22, 643-656. [CrossRef]

27. Tomkiel, M.; Baćmaga, M.; Borowik, A.; Kucharski, J.; Wyszkowska, J. Effect of a mixture of flufenacet and isoxaflutole on population numbers of soil-dwelling microorganisms, enzymatic activity of soil, and maize yield. J. Environ. Sci. Health Part B 2019, 54, 832-842. [CrossRef]

28. Delgado-Baquerizo, M.; Oliverio, A.M.; Brewer, T.E.; Benavent-González, A.; Eldridge, D.J.; Bardgett, R.D.; Maestre, F.T.; Singh, B.K.; Fierer, N. A global atlas of the dominant bacteria found in soil. Science 2018, 359, 320-325. [CrossRef]

29. Sparks, D.L. Methods of Soil Analysis, Part 3-Chemical Methods; Soil Science Society of America, Inc.: Madison, WI, USA, 1996.

30. Marín-Benito, J.M.; Andrades, M.S.; Sánchez-Martín, M.J.; Rodríguez-Cruz, M.S. Dissipation of Fungicides in a Vineyard Soil Amended with Different Spent Mushroom Substrates. J. Agric. Food Chem. 2012, 60, 6936-6945. [CrossRef]

31. Worrall, F.; Fernández-Pérez, M.; Johnson, A.C.; Flores-Cesperedes, F.; González-Pradas, E. Limitations on the role of incorporated organic matter in reducing pesticide leaching. J. Contam. Hydrol. 2001, 49, 241-262. [CrossRef]

32. Frostegård, A.; Bååth, E.; Tunlio, A. Shifts in the structure of soil microbial communities in limed forests as revealed by phospholipid fatty acid analysis. Soil Boil. Biochem. 1993, 25, 723-730. [CrossRef] 
33. Tabatabai, M.A. Soil enzymes. In Methods of Soil Analysis, Part 2-Microbiological and Biochemical Properties; Weaver, R.W., Angl, J.S., Bottomley, P.S., Eds.; Soil Science Society of America (SSSA): Madison, WI, USA, 1994; pp. 903-947.

34. Zelles, L. Fatty acid patterns of phospholipids and lipopolysaccharides in the characterisation of microbial communities in soil: A review. Boil. Fertil. Soils 1999, 29, 111-129. [CrossRef]

35. Hammer, Ø.; Harper, D.A.T.; Ryan, P.D. PAST: Paleontological Statistics software package for education and data analysis. Palaeontol. Electron. 2001, 4, 1-9.

36. Carpio, M.J.; Rodríguez-Cruz, M.S.; García-Delgado, C.; Sánchez-Martín, M.J.; Marín-Benito, J.M. Mobility monitoring of two herbicides in amended soils: A field study for modeling applications. J. Environ. Manag. 2020, 260, 110161. [CrossRef]

37. Svendsen, S.B.; Carvalho, P.N.; Bollmann, U.E.; Ellegaard-Jensen, L.; Albers, C.N.; Strobel, B.W.; Jacobsen, C.S.; Bester, K. A comparison of the fate of diflufenican in agricultural sandy soil and gravel used in urban areas. Sci. Total. Environ. 2020, 715, 136803. [CrossRef]

38. Bending, G.; Lincoln, S.D.; Edmondson, R.N. Spatial variation in the degradation rate of the pesticides isoproturon, azoxystrobin and diflufenican in soil and its relationship with chemical and microbial properties. Environ. Pollut. 2006, 139, 279-287. [CrossRef]

39. Moreno, J.L.; Bastida, F.; Sánchez-Monedero, M.A.; Hernandez, T.; Garcia, C. Response of Soil Microbial Community to a High Dose of Fresh Olive Mill Wastewater. Pedosphere 2013, 23, 281-289. [CrossRef]

40. Bai, Z.; Xu, H.-J.; He, H.-B.; Zheng, L.-C.; Zhang, X.-D. Alterations of microbial populations and composition in the rhizosphere and bulk soil as affected by residual acetochlor. Environ. Sci. Pollut. Res. 2012, 20, 369-379. [CrossRef]

41. Wu, X.; Xu, J.; Dong, F.; Liu, X.; Zheng, Y. Responses of soil microbial community to different concentration of fomesafen. J. Hazard. Mater. 2014, 273, 155-164. [CrossRef]

42. Cycoń, M.; Wójcik, M.; Borymski, S.; Piotrowska-Seget, Z. A broad-spectrum analysis of the effects of teflubenzuron exposure on the biochemical activities and microbial community structure of soil. J. Environ. Manag. 2012, 108, 27-35. [CrossRef]

43. Jorge-Mardomingo, I.; Soler-Rovira, P.; Casermeiro, M.Á.; De La Cruz, M.T.; Polo, A. Seasonal changes in microbial activity in a semiarid soil after application of a high dose of different organic amendments. Geoderma 2013, 206, 40-48. [CrossRef]

44. Álvarez-Martín, A.; Rodríguez-Cruz, M.S.; Andrades, M.S.; Sánchez-Martín, M.J. Application of a biosorbent to soil: A potential method for controlling water pollution by pesticides. Environ. Sci. Pollut. Res. 2016, 23, 9192-9203. [CrossRef] [PubMed]

45. Marinozzi, M.; Coppola, L.; Monaci, E.; Karpouzas, D.G.; Papadopoulou, E.; Menkissoglu-Spiroudi, U.; Vischetti, C. The dissipation of three fungicides in a biobed organic substrate and their impact on the structure and activity of the microbial community. Environ. Sci. Pollut. Res. 2012, 20, 2546-2555. [CrossRef] [PubMed]

46. Petrić, I.; Karpouzas, D.G.; Bru, D.; Udiković-Kolić, N.; Kandeler, E.; Djuric, S.; Martin-Laurent, F. Nicosulfuron application in agricultural soils drives the selection towards NS-tolerant microorganisms harboring various levels of sensitivity to nicosulfuron. Environ. Sci. Pollut. Res. 2015, 23, 4320-4333. [CrossRef]

47. Kalia, A.; Gosal, S.K. Effect of pesticide application on soil microorganisms. Arch. Agron. Soil Sci. 2011, 57, 569-596. [CrossRef]

(C) 2020 by the authors. Licensee MDPI, Basel, Switzerland. This article is an open access article distributed under the terms and conditions of the Creative Commons Attribution (CC BY) license (http://creativecommons.org/licenses/by/4.0/). 